Graham Brodie, Dorin Gupta, Muhammad Jamal Khan, Sally Foletta, Natalie Bootes Microwave Based Weed Control and Soil Treatment 

Graham Brodie, Dorin Gupta, Muhammad Jamal Khan, Sally Foletta, Natalie Bootes

\section{Microwave Based Weed Control and Soil Treatment}

Managing Editor: Agnieszka Topolska 
ISBN: 978-3-11-060519-8

e-ISBN: 978-3-11-060557-0

\section{(cc) BY-NC-ND}

This work is licensed under the Creative Commons Attribution-NonCommercial-NoDerivs 3.0 License. For details go to http://creativecommons.org/licenses/by-nc-nd/3.0/.

\section{Library of Congress Cataloging-in-Publication Data}

A CIP catalog record for this book has been applied for at the Library of Congress.

(C) 2018 Graham Brodie, Dorin Gupta, Muhammad Jamal Khan, Sally Foletta, Natalie Bootes Published by De Gruyter Poland, Warsaw/Berlin Part of Walter de Gruyter GmbH, Berlin/Boston

The book is published with open access at www.degruyter.com.

Managing Editor: Agnieszka Topolska

www.degruyter.com

Cover illustration: (c) Graham Brodie 